\title{
Pengaruh Jumlah Kelas Mengajar, Publikasi Ilmiah, Pengabdian dan Penunjang Terhadap Prestasi Laporan Kinerja Dosen (Survey Pada Sekolah Tinggi Ilmu Ekonomi Riau Pekanbaru)
}

\author{
ISKANDAR \\ Sekolah Tinggi Ilmu Ekonomi Riau (STIER) \\ Jln. HR. Subrantas 57 Panam Pekanbaru 28293 Telp. (0761) 63237 \\ E-mail : akbar_stier@yahoo.com
}

\begin{abstract}
The lecturer performance report becomes the responsibility of a lecturer in implementing tri dharma of higher education. This is in addition to showing the work performance of lecturers is also very supportive of the performance of study programs and in turn support universities. Problems that arise in private universities such as Riau High School of Economics which some lecturers have not been optimal in reporting the performance of lecturers. Of the many factors that influence it, this research uses four critical determinants of lecturer achievement such as the number of teaching classes, scientific publications, dedication and support. Is it true that all four variables when properly implemented then the results of lecturer work performance well. Using survey research that was disseminated online to 33 lecturers and analyzed using SEM analysis through WarPLS program, it was found that from the four variables that allegedly influenced the achievement of lecturer's performance report, only three significant and positive variables, ie learning class factor, scientific publication and support. While datu factor that is a factor of service to the public has no significant effect.
\end{abstract}

Keywords: Number of Class, Scientific Publication, Devotion, Support and Achievement of Lecturer Performance report

Masalah yang diangkat dalam penelitian ini adalah tentang keterlambatan dosen pada perguruan tinggi seasta melaporakan kinerja pada setiap periode. Selain itu juga sebagian dosen masih menganggap laporan kinerja dosen tidak memiliki nilai guna atau tidak penting sehinggga ketua prodi hanya sebatas menghimbau untuk melaporakan hasil kinerja semesternya.

Merasa kurang pentingnya laporan kinerja dosen ini membuat program studi dalam melaksanakan proses reakreditasi program studinya mengalami kendala kelengkapan berkas. Berkas yang dibutuhkan pada birang akreditasi sangat tergantung dari laporan kinerja dosen disetiap periodenya. Sehingga progrm studi selalu mengebut dan melengkapi kekurangan berkas pada waktu-waktu tertentu saja. Kondisi ini menyebabkan kualitas dari penyediaan berkas laporan terkadang dinilai dan dikritik oleh asesor (masing hangat).
Menurut Pramudyo, A. (2010). kinerja merupakan faktor yang penting bagi para dosen negeri dipekerjakan pada Kopertis Wilayah V Yogyakarta. Motivasi, kompetensi, dan kepemimpinan penting dipertimbangkan dalam menjelaskan kinerja ini. Apabila dosen mempunyai motivasi dan kompetensi yang tinggi serta didukung dengan kepemimpinan yang baik maka akan dapat meningkatkan kinerja mereka. Lingkungan kerja dalam penelitian ini tidak berpengaruh pada kinerja. Hal ini bisa menunjukkan derajat lokus of controk dosen-dosen tersebut cenderung internal, artinya aspek eksternal tidak terlalu signifikan.

Menurut Setiawati, T. (2017) menerangkan bahwa hasil analisis mengenai Kompetensi di FPTK UPI dipersepsikan tinggi, berdasarkan nilai rata-rata tanggapan responden, untuk tanggapan dengan nilai mean terkecil ada pada tanggapan pengembangan wawasan, 
baik substansial maupun tentang profesi atau pada indikator mengenai kemampuan profesional. Kinerja dari FPTK dipersepsikan tinggi berdasarkan nilai rata rata responden (tabel 4.9), untuk nilai mean terkecil ada pada tanggapan mengenai memenuhi semua perkuliahan tepat pada waktunya. Berdasarkan hasil analisis regresi menunjukan Kompetensi memiliki korelasi positif dengan kinerja. Selain itu Kompetensi memberikan pengaruh signifikan terhadap Kinerja, diketahui dari hasil uji hipotesis secara parsial.

Menurut Hamzah, H., Suyoto, S., \& Mudjihartono, P. (2015) penilaian kinerja dosen dengan metode balanced scorecard memiliki 3 strategic objectives perspektif finansial, yaitu Honorarium Dosen, Dana Hibah/Eksternal, Dana Stimulan; 2 strategic objectives perspektif pelanggan, yaitu peningkatan kepuasan mahasiswa, peningkatan kepuasan dosen; 4 strategic bjectives perspektif proses bisnis internal, yaitu Prosentase Kehadiran Dosen, Prosentase Ketersediaan soal Ujian, Prosentase Nilai Terkumpul, Bimbingan; dan 4 strategic objectives perspektif tumbuh dan belajar, yaitu Prosentase Penelitian Dosen, Prosentase Pengabdian Masyarakat, Prosentase Publikasi Ilmiah, Prosentase Pendidikan Dosen. 2. Dalam pengembangan perangkat lunak penilaian kinerja dosen secara terintegrasi berdasarkan sumber data dari setiap unit pendukung pada institusi maka terdapat beberapa subsistem-subsistem yaitu: Sub sistem EKEU, Subsistem EDOM, Subsistem EDOS, Subsistem EBAK, Subsistem EPRODI, Subsistem EP3M, Subsistem PSDM.

Sedangkkan menurut Bilmoneva, L., \& Hari Kusnanto J, D. (2005) menunjukkan bahwa kinerja dipengaruhi komitmen dan persepsi terhadap organisasi, umur, pendidikan, beban mengajar pada semester yang lalu dan bekerja di tempat lain. Komitmen terhadap organisasi merupakan faktor yang mempunyai determinasi paling kuat terhadap kinerja administrasi. Tingkat kehadiran dipengaruhi oleh komitmen, pendidikan, masa kerja dan bekerja di tempat lain. Faktor dominan yang mempengaruhi tingkat kehadiran adalah dosen bekerja di tempat lain. Kesimpulan. Komitmen berhubungan dengan kinerja administrasi dan tingkat kehadiran dosen dalam proses belajar mengajar.

Sedangkan menurut Purwaningsih, R., \& Sugiyanto, A. (2007). Beban kerja mental terbesar yang dialami dosen Teknik Industri adalah pada saat melaksanakan kegiatan pengajaran dan beban ini masih termasuk kategori sedang. Sedangkan permasalahan yang muncul adalah dari tiap dimensi, yaitu rendahnya beban waktu dosen dalam melaksanakan pengabdian kepada masyarakat, tingginya beban usaha mental pendidikan dan bimbingan serta cukup tingginya beban tekanan psikologis penelitian, sehingga usulan perbaikan sistem kerja yang dilakukan dikaitkan dengan permasalahan tersebut.

Berdasarkan permasalah dan tinjauan teori ditemukan kesenjangan yang mengarah kepada penggunaan indikator atau variabel yang berbeda yang mempengaruhi laporan kinerja dosen. Hal unik yang diteliti dalam penelitian ini sebagai bentuk inovasi menerapkan vaiabel tri dharma sebagai faktor yang dianggap mempengaruhi prestasi laporan kinerja dosen.

\section{METODE}

Jenis penelitian yang digunakan adalah penelitian survey. Survey dilakukan dengan menggunakan kuesioner online yang disebarkan kepada 33 orang dosen pada sekolah tinggi ilmu ekonomi riau dengan teknik pengambilan sampel sensus. Data yang dikumpul dianalisis dengan analisis SEM menggunakan program WarPLS.

\section{HASIL}

Berdasarkan hasil penelitian yang dilakukan di lapangan, diperoleh beberapa informasi yang berkaitan dengan prestasi laporan kinerja dosen. 
Gambar 1

Model Prestasi Laporan Kinerja Dosen

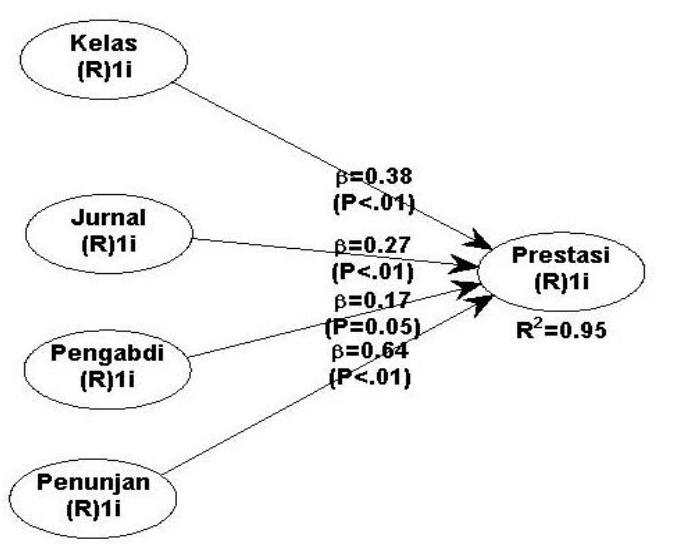

Berdasarkan hasil penelitian menunjukkan bahwa jumlah kelas mengajar memiliki pengaruh yang positif dan signifikan terhadap prestasi laporan kinerja dosen dengan diperoleh hasil $(\mathrm{P}<0,01)$.

Berdasarkan hasil penelitian menunjukkan bahwa publikasi karya ilmiah memiliki pengaruh yang positif dan signifikan terhadap prestasi laporan kinerja dosen dengan diperoleh hasil $(\mathrm{P}<0,01)$.

Berdasarkan hasil penelitian menunjukkan bahwa pengabdian kepada masyarakat tidak memiliki pengaruh yang positif dan signifikan terhadap prestasi laporan kinerja dosen dengan diperoleh hasil $(\mathrm{P}<0,64)$.

Berdasarkan hasil penelitian menunjukkan bahwa penunjang memiliki pengaruh yang positif dan signifikan terhadap prestasi laporan kinerja dosen dengan diperoleh hasil $(\mathrm{P}<0,01)$.

\section{PEMBAHASAN}

Berdasarkan hasil pengujian yang dilakukan untuk mengukur pengaruh prestasi laporan kinerja dosen yang dilihat dari empat variabel yaitu jumlah kelas mengajar, publikasi jurnal ilmiah, pengabdian dan penunjang). Dari hasil penelitian diperoleh hasil bahwa dari keempat variabel yang diduga mempengaruhi prestasi laporan kinerja dosen, terbukti hanya tiga variabel yang signifikan dan positif, yakni faktor kelas menagajar, publikasi ilmiah dan penunjang. Sedangkan datu faktor yakni faktor pengabdian kepada masyarakat tidak berpengaruh secara signifikan.

Hasil penelitian yang dilakukan bertentangan dengan hasil penelitian yang dilakukan oleh Pramudyo, A. (2010). Dimana menurut Pramudyo, A. (2010). kinerja merupakan faktor yang penting bagi para dosen negeri dipekerjakan pada Kopertis Wilayah V Yogyakarta. Motivasi, kompetensi, dan kepemimpinan penting dipertimbangkan dalam menjelaskan kinerja ini. Apabila dosen mempunyai motivasi dan kompetensi yang tinggi serta didukung dengan kepemimpinan yang baik maka akan dapat meningkatkan kinerja mereka. Lingkungan kerja dalam penelitian ini tidak berpengaruh pada kinerja. Hal ini bisa menunjukkan derajat lokus of controk dosen-dosen tersebut cenderung internal, artinya aspek eksternal tidak terlalu signifikan. Sedangkkan menurut Bilmoneva, L., \& Hari Kusnanto J, D. (2005) menunjukkan bahwa kinerja dipengaruhi komitmen dan persepsi terhadap organisasi, umur, pendidikan, beban mengajar pada semester yang lalu dan bekerja di tempat lain. Komitmen terhadap organisasi merupakan faktor yang mempunyai determinasi paling kuat terhadap kinerja administrasi. Tingkat kehadiran dipengaruhi oleh komitmen, pendidikan, masa kerja dan bekerja di tempat lain. Faktor dominan yang mempengaruhi tingkat kehadiran adalah dosen bekerja di tempat lain. Kesimpulan. Komitmen berhubungan dengan kinerja administrasi dan tingkat kehadiran dosen dalam proses belajar mengajar.

\section{SIMPULAN}

Dari penelitian yang dilakukan di atas bahwa hasil penelitian dari keempat variabel yang diduga mempengaruhi prestasi laporan kinerja dosen, terbukti hanya tiga variabel yang signifikan dan positif, yakni faktor kelas menagajar, publikasi ilmiah dan penunjang. Sedangkan datu faktor yakni faktor pengabdian kepada masyarakat tidak berpengaruh secara

p.ISSN: $2407-800 X \quad$ e.ISSN: 2541-4356 
signifikanhasil bahwa dari keempat variabel yang diduga mempengaruhi prestasi laporan kinerja dosen, terbukti hanya tiga variabel yang signifikan dan positif, yakni faktor kelas menagajar, publikasi ilmiah dan penunjang. Sedangkan satu faktor yakni faktor pengabdian kepada masyarakat tidak berpengaruh secara signifikan terhadap prestasi laporan kinerja dosen.

\section{DAFTAR RUJUKAN}

Pramudyo, A. (2010). Analisis Faktor-Faktor yang Mempengaruhi Kinerja Dosen Negeri Pada Kopertis Wilayah V Yogyakarta. Jurnal Bisnis Teori \& Implementasi, 1(1), 1-11.

Setiawati, T. (2017). Pengaruh Kompetensi Kerja Terhadap Kinerja Dosen. Media Pendidikan, Gizi, dan Kuliner, 1(1).

Hamzah, H., Suyoto, S., \& Mudjihartono, P. (2015, July). Sistem Pendukung Keputusan Penilaian Kinerja Dosen Dengan Metode Balanced Scorecard (Studi Kasus: Universitas Respati Yogyakarta). In Seminar Nasional Informatika (SEMNASIF) (Vol. 1, No. 5).
Bilmoneva, L., \& Hari Kusnanto J, D. (2005). Hubungan antara komitmen terhadap organisasi dengan kinerja Dosen Pembelajaran Klinik di Akper Swasta di Pekanbaru (Doctoral dissertation, Universitas Gadjah Mada).

Purwaningsih, R., \& Sugiyanto, A. (2007). Analisis Beban Kerja Mental Dosen Teknik Industri Undip Dengan Metode Subjective Workload Assessment Technique (Swat).J@TI UNDIP: JURNAL TEKNIK INDUSTRI, 2(2), 28-39. 